\title{
Aggregations of Southern Caracaras (Caracara plancus) in soybean plantations in central Cerrado, Brazil
}

\author{
Dárius Pukenis Tubelis ${ }^{1,2}$ \\ Departamento de Biociências, Universidade Federal Rural do Semi-Árido, Campus Mossoró, Mossoró, RN, Brazil. \\ 2 Corresponding author: darius.tubelis@gmail.com
}

Received on 15 October 2018. Accepted on 12 March 2019.

\begin{abstract}
This study reports on large aggregations of Southern Caracaras (Caracara plancus) in soybean plantations in the surroundings of Parque Nacional das Emas, southwestern Brazil. Observations were done during harvesting activities in February 2009. Aggregations were found by driving a vehicle through roads that crossed or bordered soybean plantations located at less than $4 \mathrm{~km}$ from this park. For each aggregation detected, individuals found around harvesting machines were counted. The abundance of Southern Caracaras of each aggregation ranged between 76 and 104 individuals $(n=8)$. Despite the attraction of high numbers of caracaras to proximities of machines, most of them appear to do not obtain much food resources during harvesting of soybean fields. Caracaras were seen capturing small mammals, lizards, birds and large insects. This association between $C$. plancus and harvesting activities can be considered as opportunist behavior in response to rapid modification of grain-production landscapes in the Cerrado.
\end{abstract}

KEY-WORDS: agribusiness, bird, Falconidae, feeding ecology, grassland, savanna.

In the Cerrado, the savanna ecosystem that dominates central Brazil, landscapes were originally dominated by open vegetation such as grasslands and woodlands (Oliveira \& Marquis 2002). However, extensive areas of these matrix types have been converted to agricultural land during the last three decades (Klink \& Machado 2005). As consequence, numerous landscapes are now covered mainly by exotic vegetation such as soybean plantations (Klink \& Moreira 2002). Despite this dramatic modification of landscapes, the use of soybean plantations by native wildlife remains poorly investigated in the Cerrado.

Some bird species, such as the Southern Caracara (Caracara plancus) can be occasionally found in soybean fields (pers. obs.). This raptor species is associated to open vegetation and human-modified landscapes in the Neotropical region (Ferguson-Lees \& Christie 2001, Erize et al. 2006, Sazima 2007). It is usually found in landscape elements such as grasslands, savannas, pastures, agricultural fields, roads and urban areas (del Hoyo et al. 1994, Sick 1997, Narosky \& Yzurieta 2006). Its omnivorous diet includes a wide range of alive and dead animals, plants and human-made food (Wallace $\&$ Temple 1987, Ferguson-Lees \& Christie 2001, Travaini et al. 2001, Galetti \& Guimarães-Jr. 2004, Vargas et al. 2007). In the Cerrado, lone birds or pairs of this species often feed on the ground of open areas (Antas \& Cavalcanti 1988), including the consumption of rodents, lizards, beetles and grasshoppers in harvested soybean plantations (pers. obs.). This study aimed to report on large aggregations of the Southern Caracara in soybean plantations during harvesting operations in a central Brazilian Cerrado.

Observations were done in the surroundings of

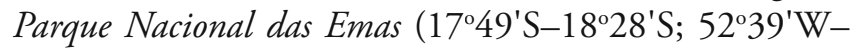
$\left.53^{\circ} 10^{\prime} \mathrm{W}\right)$, a $1330 \mathrm{~km}^{2}$ nature reserve located in Goiás state, central Cerrado, southwestern Brazil. Elevations range between 720 and $900 \mathrm{~m}$ a.s.l., and most of the original landscape consists of flat tableland covered by grasslands and open woodlands (França et al. 2007). Climate is marked by two well defined periods, wet and dry seasons. Most of the annual precipitation falls between October and March. Annual rainfall ranges between 1200 and $2000 \mathrm{~mm}$ (Assad 1994). The park is mostly surrounded by agricultural land, such as soybean, cotton and corn plantations. Soybean plantations usually occur between early November and late February and a single stand might cover several $\mathrm{km}^{2}$ (pers. obs.).

Cultivation and harvesting of soybean fields in the study area are made mechanically. Large machines (colheitadeiras) usually harvest plantations in mid or late February. To harvest a given stand, these machines are usually driven straight for about $600-2000 \mathrm{~m}$ and then moved in opposite way, to pass over juxtaposed areas of plantations still not harvested. Thus, bands of clear cuts (harvested areas) of about $10 \mathrm{~m}$ in width are created in sequence.

Observations were done during afternoons between 
17 and 22 February 2009, when most soybean plantations in this Cerrado region were being harvested. To search for caracara aggregations associated with harvesting activities, I drove a vehicle through roads that crossed or bordered soybean plantations located at less than $4 \mathrm{~km}$ from the park. When harvesting machines surrounded by numerous caracaras were detected, I left the vehicle and approached them by walking. Caracaras located around the harvesting machines were counted. Usually, I spent about 10 min for each aggregation and I could get at less than $200 \mathrm{~m}$ from most of the individuals, which were easily seen from this distance (Fig. 1).

Eight large aggregations of $C$. plancus associated with machines harvesting soybean fields were recorded. The numbers of individuals detected in each aggregation were: $96,104,76,85,94,88,79$ and 82 . Studies in the Cerrado and elsewhere reported that $C$. plancus usually forages solitary or in pairs, while groups of three to nine birds have been recorded sporadically (Whitacre et al. 1982, Antas \& Cavacanti 1988, Yosef \& Yosef 1992, del Hoyo et al. 1994, Sick 1997, Goldstein \& Hibbitts 2004). These numbers are comparable to those found by myself in young soybean plantations in the study area during late 2006 and 2008. In relation to the aggregations reported in this study, most caracaras foraged lonely or in pairs, and not cooperatively as reported by Jones (1999) for the Mountain Caracara (Phalcoboenus megalopterus) in Peru. Additionally, in his review of the feeding habits of C. plancus, Sazima (2007) also reported that this species follows ploughs in South America. As social learning of foraging in birds might occur by the observation of conspecifics at feedings sites (see review in Slagsvold \& Wiebe 2011), it is possible that these raptors were able to associate moving machines to the availability of food items during harvesting operations.

Estimates of abundance of $C$. plancus in the Cerrado

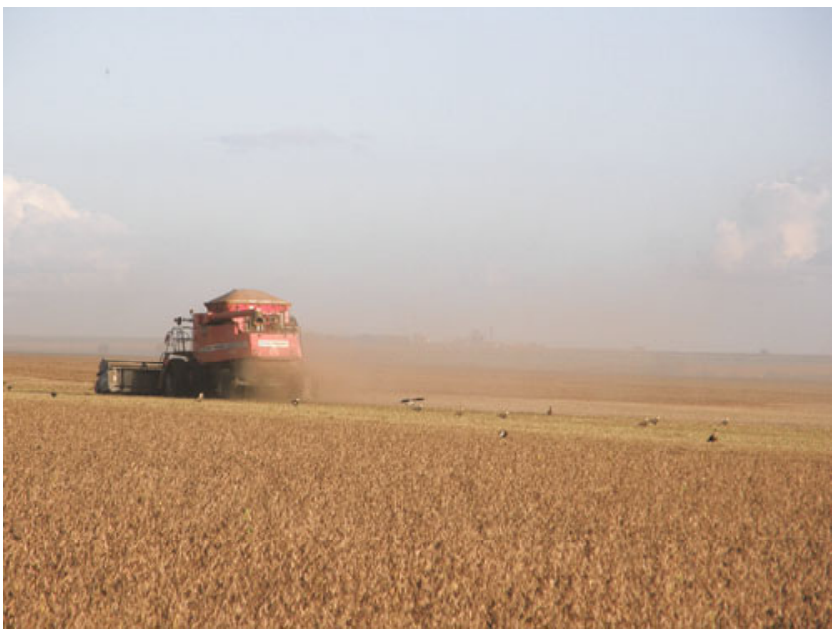

Figure 1. Numerous Southern Caracaras (Caracara plancus) attracted by harvesting activities in soybean fields close to Parque Nacional das Emas, southwestern Brazil, in February 2009. and other regions were mostly done through transect routes. For example, its density at Parque Nacional das Emas was estimated as $2.8 \pm 1.6$ individuals $/ \mathrm{km}^{2}$ (Baumgarten 1998). In the Venezuelan Llanos, Jensen $e t$ al. (2005) reported less than 20 birds per $22.5 \mathrm{~km}$ long counts. Similar surveys conducted in other landscapes reported comparable or lower densities (Albuquerque $e t$ al. 1986, Hayes 1991, Carvalho \& Marini 2007). Thus, the aggregations reported in the current study are the highest densities of foraging $C$. plancus recorded to date, as they usually kept within an area of about 10 ha around the machines.

During the removal of soybean vegetation, caracaras tended to keep on the ground of recently harvested fields. Most of them usually kept nearly stopped watching the machine or walking slowly in search of food resources on the ground, as commonly observed in South America (Sazima 2007). Relatively few individuals followed the machines for a few meters by flying or running short distances in an attempt to capture animals flushed due the disturbance on vegetation. Similarly, Sick (1997) reported the following of tractors by this raptor species in search of earthworms during field plowing in Brazil.

The consumption of soybean grains by caracaras has not been observed in this study. On few occasions, caracaras were observed obtaining food resources (unidentified rodents, lizards, birds and large insects, such as beetles and grasshoppers). After holding prey with the bill, caracaras left the aggregations. Likely, these prey were injured or incapacitated by machines. Despite the recording of these feeding events, food availability appeared to not be plentiful in the areas being harvested. This is because most individuals observed in detail after the 10 min counting periods have not obtained food items. This low number of feeding events recorded might not result of the short period of sampling in each plantation. I consider that, as these raptors were numerous, I would often record foraging birds if food items were abundant, even during a short period.

Thus, despite the attraction of outstanding numbers of caracaras to the surrounding of active machines, most caracaras did not obtain large amounts of food during the harvest of soybean fields. This observed low consumption of food items by this raptor species in the studied plantations might result, in part, of applications of agrochemicals to soybean plants. This practice might cause the killing of the invertebrates and vertebrates that arrive in plantations. Further, as the studied plantations were usually at more than $2 \mathrm{~km}$ from the park and other native remnants, it is likely that few animals could colonize these exotic fields.

This is because I could observe a few caracaras, groups of the Greater Rhea Rhea americana, and pairs of the Yellow-headed Caracara Milvago chimachima, the 
Red-legged Seriema Cariama cristata, the Burrowing Owl Athene cunicularia and the Southern Lapwing Vanellus chilensis eating numerous prey consecutively by following a machine in early 2007 . On this occasion, these birds were at less than $100 \mathrm{~m}$ from the park, where agrochemicals were not applied due an agreement between the land owner and the park manager. Therefore, I consider that these bands of plantations free of agrochemicals located adjacent to park boundaries could be colonized by numerous invertebrates and vertebrates due to a short distance from native areas of the park.

The experience with great food availability as result of machine movement juxtaposed to the park might explain this aggregation of caracaras in the studied fields and elsewhere due to learning. Further studies are necessary to verify if this opportunist behavior of $C$. plancus in response to rapid modification of agricultural landscapes in the Cerrado is leading to their intoxication.

\section{ACKNOWLEDGEMENTS}

I thank Mário B. Ramos-Neto (CI-Brasil) for providing a map of the study area. Luís Inoue and two anonymous reviewers greatly improved this manuscript with constructive suggestions. This study was financed by FAPESP (Proc. 05/00773-3), CNPq (Proc. 471360/2006-6) and the Neotropical Grassland Conservancy. Universidade Federal Rural do Semi-Árido provided logistic support during the writing process.

\section{REFERENCES}

Albuquerque J.L.B., Witech A.J. \& Aldous A.M. 1986. A roadside count of diurnal raptors in Rio Grande do Sul, Brazil. Bird of Prey Bulletin 3: 82-87.

Antas P.T.Z. \& Cavalcanti R.B. 1988. Aves comuns do planalto central. Brasília: Editora da Universidade de Brasília.

Baumgarten L.C. 1998. Ecologia dos Falconiformes de áreas abertas do Parque Nacional das Emas (Mineiros-GO). MSc. Dissertation. Campinas: Universidade Estadual de Campinas.

Carvalho C.E.A. \& Marini M.Â. 2007. Distribution patterns of diurnal raptors in open and forested habitats in south-eastern Brazil and the effects of urbanization. Bird Conservation International 17: 367-380.

del Hoyo J., Elliott A. \& Sargatal J. 1994. Handbook of the birds of the world, v. 2 (New World vultures to Guineafowl). Barcelona: Lynx Editions.

Embrapa. 2018. Embrapa soja. https://www.embrapa.br/soja (Access on 10 October 2018).
Erize F., Mata J.R.R. \& Rumboll M. 2006. Birds of South America: non-Passerines: rheas to woodpeckers. Oxford: Princeton University Press.

Ferguson-Lees J. \& Christie D.A. 2001. Raptors of the world. Boston: Houghton Mifflin Company.

França H., Ramos-Neto M.B. \& Setzer A. 2007. O fogo no Parque Nacional das Emas. Brasília: Ministério do Meio Ambiente.

Galetti M. \& Guimarães-Jr. P.R. 2004. Seed dispersal of Attalea phalerata (Palmae) by Crested Caracaras (Caracara plancus) in the Pantanal and a review of frugivory by raptors. Revista Brasileira de Ornitologia 12: 133-135.

Goldstein M.I. \& Hibbitts T.J. 2004. Summer roadside raptor surveys in the western Pampas of Argentina. Journal of Raptor Research 38: 152-157.

Hayes F.E. 1991. Raptor densities along the Paraguay River: seasonal, geographical and time of day variation. Journal of Raptor Research 25: 101-108.

Jensen W.J., Gregory M.S., Baldassarre G.A., Villela F.J. \& Bildstein K.L. 2005. Raptor abundance and distribution in the Llanos wetlands of Venezuela. Journal of Raptor Research 39: 417-428.

Jones J. 1999. Cooperative foraging in the Mountain Caracara in Peru. Wilson Bulletin 111: 437-439.

Klink C.A. \& Machado R.B. 2005. Conservation of the Brazilian Cerrado. Conservation Biology 19: 707-713.

Klink C.A. \& Moreira A.G. 2002. Past and current human occupation, and land use, p. 69-88. In: Oliveira P.S. \& Marquis R.J. (eds.). The Cerrados of Brazil: ecology and natural history of a Neotropical savanna. New York: Columbia University Press.

Narosky T. \& Yzurieta D. 2006. Guía para la identificación de las aves de Paraguay. Asunción: Guyra Paraguay.

Oliveira P.S. \& Marquis R.J. 2002. The Cerrados of Brazil: ecology and natural history of a Neotropical savanna. New York: Columbia University Press.

Sazima I. 2007. The jack-of-all-trades raptor: versatile foraging and wide trophic role of the Southern Caracara (Caracara plancus) in Brazil, with comments on feeding habits of the Caracarini. Revista Brasileira de Ornitologia 15: 592-597.

Sick H. 1997. Ornitologia brasileira. Rio de Janeiro: Editora Nova Fronteira.

Slagsvold T. \& Wiebe K.L. 2011. Social learning in birds and its role in shaping a foraging niche. Philosophical Transactions of the Royal Society B: Biological Sciences 366: 969-977.

Travaini A., Donázar J.A., Ceballos O. \& Hiraldo F. 2001. Food habits of the Crested Caracara (Caracara plancus) in the Andean Patagonia: the role of breeding constraints. Journal of Arid Environments 48: 211-219.

Vargas R.J., Bó M.S. \& Favero M. 2007. Diet of the Southern Caracara (Caracara plancus) in Mar Chiquita reserve, southern Argentina. Journal of Raptor Research 41: 113-121.

Wallace M.P. \& Temple S.A. 1987. Competitive interactions within and between species in a guild of avian scavengers. Auk 104: 290-295.

Whitacre D., Ukrain D. \& Falxa G.A. 1982. Notes on the hunting behavior and diet of the Crested Caracara in northeastern Chiapas and Tabasco, Mexico. Wilson Bulletin 94: 565-566.

Yosef R. \& Yosef D. 1992. Hunting behavior of Audubon's Crested Caracara. Journal of Raptor Research 26: 100-101.

Associate Editor: Marcos P. Dantas. 